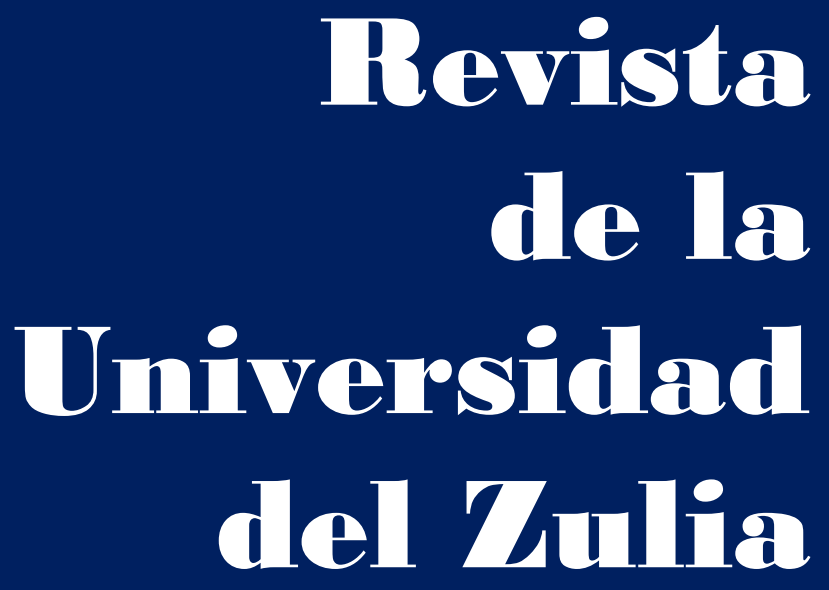

Fundada en 1947

por el Dr. Jesús Enrique Lossada

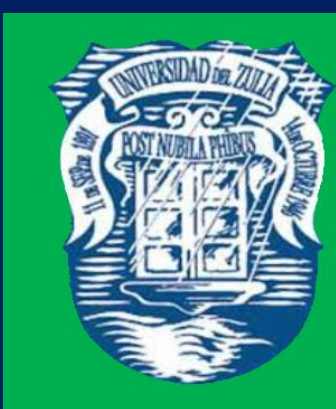

Ciencias del

Agred

Ingemieria

y Teenología
Añต 12 No 32

Enero - Abril 2021

Tercera Época

Maracailbo-Venezuela 
REVISTA DE LA UNIVERSIDAD DEL ZULIA. 3ª época. Año 12 N³2, 2021

Danil Alekseevich Zyukin et al. // Directions and prospects for expanding the export ... 87-101

DOI: http://dx.doi.org/10.46925//rdluz.32.07

\title{
Directions and prospects for expanding the export of russian wheat
}

\author{
Danil Alekseevich Zyukin * \\ Olga Nikolaevna Pronskaya ** \\ Olga Viktorovna Svyatova *** \\ Artem Alekseevich Golovin **** \\ Olga Viktorovna Pshenichnikova ***** \\ Olga Vyacheslavovna Petrushina ******
}

\begin{abstract}
The grain economy of Russia has now reached a new high level of development, providing ample opportunities for the expansion of Russian grain to the world market. The research reveals the following main threats to further strengthening the position of Russian wheat in the world market: instability of yields and inappropriate production and logistics infrastructure, which determines overestimated transaction costs and low flexibility of supply. The article analyzes the structure of importers of Russian wheat to characterize the instability of the world wheat market and high competition on it. The aim of the research is to form key directions for ensuring the sustainability and efficiency of wheat exports. The development of the grain product subcomplex of the Russian agro-industrial complex is presented by the authors from the position of priority in ensuring the food security of the population by fully meeting the needs of the domestic market, while exports are assigned the role of an instrument for regulating the grain market. Increasing wheat exports is not a priority for the development of grain farming; however, under the current conditions, this is the main incentive for increasing grain production and a way of obtaining foreign exchange income for agrarians. In this regard, it seems necessary to increase the regulatory role of the state in managing the country's grain balance and intensify investment processes in the industry through improving the country's fiscal and monetary policy in relation to the agricultural sector.
\end{abstract}

KEY WORDS: grain farming, wheat, export, government regulation, production and logistics infrastructure, efficiency

${ }^{*}$ Candidate of sciences of Economic, Senior researcher Kursk state agricultural academy named after I.I. Ivanov

**Doctor of sciences of Economic, Professor, head of the department of management, marketing and personnel management Kursk State University

*** Doctor of sciences of Economic, Professor of the department of Economics and accounting Kursk State University

${ }^{* * * *}$ Candidate of sciences of Economic, Associate professor of the department of customs and world economy Southwestern State University

****Candidate of sciences of Economic, Associate professor of the department of Economics and accounting Kursk State University

******Head of international Department Kursk state agricultural Academy named after I.I. Ivanov

Recibido: 30/10/2020

Aceptado: 03/12/2020 


\section{Directrices y perspectivas para expandir la exportación de trigo} ruso

RESUMEN

La economía de cereales de Rusia ha alcanzado ahora un nuevo alto nivel de desarrollo, proporcionando amplias oportunidades para la expansión del grano ruso en el mercado mundial. La investigación revela las siguientes amenazas principales para fortalecer aún más la posición del trigo ruso en el mercado mundial: inestabilidad de los rendimientos e infraestructura de producción y logística inadecuada, lo que determina costos de transacción sobreestimados y baja flexibilidad de suministro. El artículo analiza la estructura de los importadores de trigo ruso para caracterizar la inestabilidad del mercado mundial de trigo y la alta competencia en él. El objetivo de la investigación es aportar orientaciones para asegurar la sostenibilidad y eficiencia de las exportaciones de trigo. El desarrollo del subcomplejo de productos de cereales del complejo agroindustrial ruso es presentado por los autores desde la posición de prioridad para garantizar la seguridad alimentaria de la población al satisfacer plenamente las necesidades del mercado interno, mientras que a las exportaciones se les asigna el papel de un instrumento de regulación del mercado de cereales. El aumento de las exportaciones de trigo no es una prioridad para el desarrollo del cultivo de cereales; sin embargo, en las condiciones actuales, este es el principal incentivo para incrementar la producción de granos y una forma de obtener ingresos en divisas para los agrarios. En este sentido, parece necesario incrementar el rol regulador del Estado en la gestión del balance de granos del país e intensificar los procesos de inversión en la industria mediante la mejora de la política fiscal y monetaria del país en relación con el sector agrícola.

PALABRAS CLAVE: cultivo de granos, trigo, exportación, regulación gubernamental, infraestructura de producción y logística, eficiencia

\section{Introduction}

The Russian economy did not fully recover from the 2008 global economic crisis. Therefore, the sanctions imposed by a number of leading economies, against the background of political and economic contradictions in 2014, had a negative impact on the Russian economy. An additional blow to the current and long-term economic prospects of Russia was inflicted by the unstable price environment in the energy market, the industries of which are the main sources of budget revenues and at the same time the most competitive in the country's economy. It is very important to support areas that have a high export potential in this situation.

In the recent past, Russia was a large net importer of the world agri-food market. The development of domestic agriculture made it possible to partially solve the problems in a 
REVISTA DE LA UNIVERSIDAD DEL ZULIA. 3ª época. Año 12 N 32, 2021

Danil Alekseevich Zyukin et al. // Directions and prospects for expanding the export ... 87-101

DOI: http://dx.doi.org/10.46925//rdluz.32.07

number of groups of food products, creating export potential in some areas. Nevertheless, the threat to food and agricultural security for the Russian population and agricultural producers remains very real (Zavriev and Ignatov, 2020). Conditions have been created for the production of products in a number of areas of agricultural production, which significantly exceed domestic needs. In recent years, a significant surplus has formed between the production and consumption of wheat, which predetermines the stimulation of exports as a condition for the reorganization of the domestic agri-food market (Svetlov, 2016). This problem is becoming more and more urgent for the sugar beet subcomplex of the agroindustrial complex, which has already reached the limit of the domestic market, but there are still few opportunities to enter other markets, which hinders its further development (Zyukin et al., 2016).

The state of Russian agriculture until relatively recently for the country caused an outflow of financial resources, and today it allows the formation of foreign exchange earnings at a level comparable to the income from the sale of weapons. Belova T.N. notes that rural commodity producers have received several preferences for production growth since August 2014: an embargo on food imports, government support and a weakening of the national currency (Belova, 2019). It was planned to reach the volume of exports of agricultural products in the amount of 25 billion dollars in 2020, but the figure was 26.5 billion dollars by December. The most important role in the development of all agriculture in Russia and increasing its export potential is played by grain farming, which is a multiplicative industry that determines the competitiveness of products in related industries.

The expansion of Russia's opportunities for exporting grain is based on its underconsumption in the domestic market for feed purposes in animal husbandry due to a decrease in the number of livestock in comparison with the Soviet period (Altukhov, 2017). This predetermined the current structure of production, where export-oriented wheat occupies the main place. This is especially true for the southwestern regions of the country, which have the highest agro-climatic potential and are located close to sea transport routes, which predetermines the formation of their production and economic policy in favor of exports (Krylatykh and Belova, 2018). It also determines their price competitiveness in export: the return on the invested resources under the best natural and climatic conditions 
REVISTA DE LA UNIVERSIDAD DEL ZULIA. 3ª época. Año 12 N 32, 2021

Danil Alekseevich Zyukin et al. // Directions and prospects for expanding the export ... 87-101

DOI: http://dx.doi.org/10.46925//rdluz.32.07

is higher, and logistics to port transshipment are significantly cheaper than in the regions of the central part of Russia (Generalov, 2018).

\section{Methodology}

It is proposed to develop export prospects for Russian wheat based on the principle of priority of the needs of the domestic agri-food market in Russia. Wheat is an exportoriented agricultural crop, therefore, a further bias towards its production, especially of a low class, can lead to a shortage of other crops that are used to provide a fodder base for livestock. The concentration on wheat of 4 and 5 classes in export-oriented regions of Russia also determines the shortage of durum wheat used for the production of high-class flour, since there are no necessary natural and climatic conditions for cultivation in other regions of Russia.

A set of regulatory state measures is proposed as the main direction for managing the balance of grain in the country. The key element in the development of the grain-product sub-complex of the agro-industrial complex is the improvement of the production and logistics infrastructure, which ensures a decrease in transport costs and an increase in the flexibility and speed of grain deliveries both in the country and on the world market.

The improvement of Russia's competitive position in the world market for grain crops and wheat separately is assessed through an increase in the physical volume of exports and foreign exchange income. The study analyzes the structure of the main importers of Russian wheat to prove the instability of the market situation and the need for constant development of foreign trade partnerships and increasing the competitiveness of wheat, primarily in terms of price by reducing transaction costs.

\section{Theoretical basis}

Grain farming is a backbone element of the agro-industrial complex of Russia, influencing the formation of a competitive fodder base for animal husbandry and being the main element of the crop rotation system. To date, significant progress has been made in grain production in ensuring food security of the country's population and a significant export potential has been formed. This predetermined the growing role of agriculture in the structure of Russian exports. If the share of agricultural raw materials and foodstuffs in the 
REVISTA DE LA UNIVERSIDAD DEL ZULIA. 3ª época. Año 12 N 32, 2021

Danil Alekseevich Zyukin et al. // Directions and prospects for expanding the export ... 87-101

DOI: http://dx.doi.org/10.46925//rdluz.32.07

total value of Russian exports accounted for $1.8 \%$ in 2000, the figure was at the level of 3.2$3.4 \%$ in $2009-2013$ and reached $6 \%$ by 2016 , which is maintained in subsequent years. The increase in the indicator is due to the increase in the export potential of grain and oilseed processing products with a decrease in energy prices. In the future, the role of agriculture and the grain industry as the main export direction will continue to grow, while the instability in the oil and gas market remains.

The share of wheat in the physical volume of exports of cereals and legumes reaches $80 \%$ in different years. Only barley and corn can be distinguished as relatively significant crops in the structure of grain exports, which account for $9.6 \%$ and $7.7 \%$ as of 2019. In addition to these crops, Russia exports 10 more types of grain and leguminous crops, but their export is fragmented. This determines the role of wheat as the "queen of the fields" in the structure of crop production in most of the agrarian regions of Russia.

Due to a significant surplus in the domestic market, exports have become an effective instrument of reorganization, allowing Russian farmers to receive significant foreign exchange income. There are significant disadvantages of the formation of the task of increasing the export of grain as a priority, which forms the structure of domestic exportoriented production. This structure can lead to a technological gap between the development of grain farming and animal husbandry in the context of the need to ensure food security of the population and to carry out import substitution of food products. The consequence of this may be disruptions in the interaction between natural-biological, technicaltechnological and socio-economic factors that determine the stability of the Russian agrifood market. Therefore, it is important to approach further increasing the export potential of grain farming, taking into account the strategic interests of the development of agriculture in Russia and the food security of its citizens.

The fundamental measure to increase the efficiency of exports should be the development of production and logistics infrastructure, which would ensure the safety of the harvested crop to its buyers in the Russian and world markets. Increasing price competitiveness by lowering transaction costs will further expand the expansion of Russian grain to remote markets in Atlantic Africa and Southeast Asia. In the context of the structural crisis in the Russian economy and the limited access of Russian companies to the financial 
REVISTA DE LA UNIVERSIDAD DEL ZULIA. 3ª época. Año 12 N 32, 2021

Danil Alekseevich Zyukin et al. // Directions and prospects for expanding the export ... 87-101

DOI: http://dx.doi.org/10.46925//rdluz.32.07

markets of developed countries, the state's position in the field of investment regulation of projects in this area is key.

\section{Results}

Grain is the main export product of Russian agriculture. After abnormal weather conditions in 2010 and the announcement of an embargo on grain exports by 2020, Russia has managed to become one of the main players in the global grain market. A qualitative transition took place in 2014-2016, when export volumes increased from 20 million tons to 30-35 million tons of grain. The climax of success was 56.2 million tons of grain exported abroad in 2018. The conditions for grain production in 2019 were not so good, however, the level remained above 40 million tons (Figure 1 ).

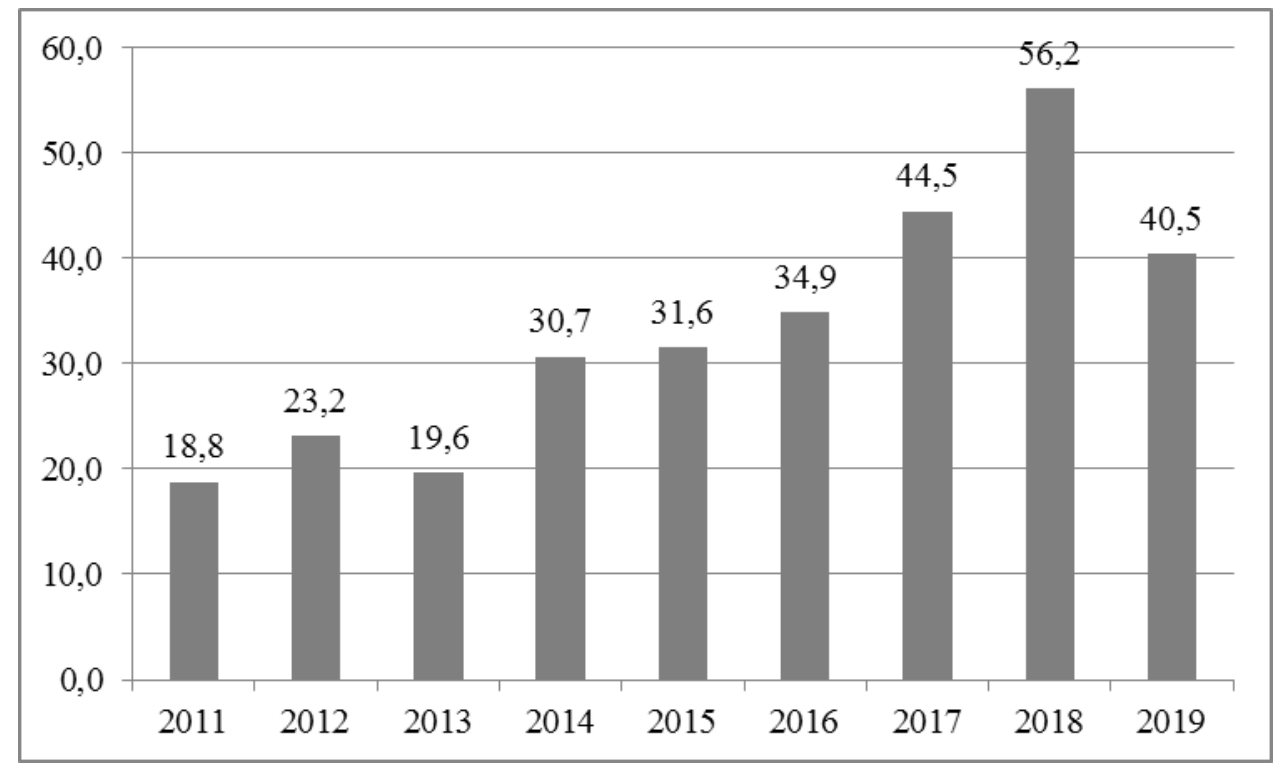

Figure 1. The value of Russian grain exports in 2011-2019, million tons.

Compiled by the authors based on the source agribusiness expert and analytical center.ru (Statistics of agricultural raw materials and food markets, $\mathrm{n} / \mathrm{d}$ )

At the beginning of 2020, the Ministry of Agriculture considered the option of introducing restrictive quotas on grain exports in the second half of the year, depending on the harvest, at the level of 25 million tons. However, the harvested crop was higher than the planned indicators, surpassing all the results of previous years. As of December 1 , more than 138 million tons of grain have been threshed, which is a new record. This made it possible to continue the active expansion of Russian grain to the world market. From July l to October 
REVISTA DE LA UNIVERSIDAD DEL ZULIA. 3ª época. Año 12 N 32, 2021

Danil Alekseevich Zyukin et al. // Directions and prospects for expanding the export ... 87-101

DOI: http://dx.doi.org/10.46925//rdluz.32.07

31, Russia exported more than 18 million tons of grain (which is $7.1 \%$ higher than last year's figure), including 15.7 million tons of wheat.

The importance of success in increasing grain exports for agrarians is determined by the receipt of foreign exchange earnings, the amount of which almost doubled, if we consider the average value in 2018 - 2019 relative to the level of 2011 (Figure 2). Revenues in 2020 have already surpassed the prior period and are expected to reach the landmark 10 billion dollars by the end of the year.

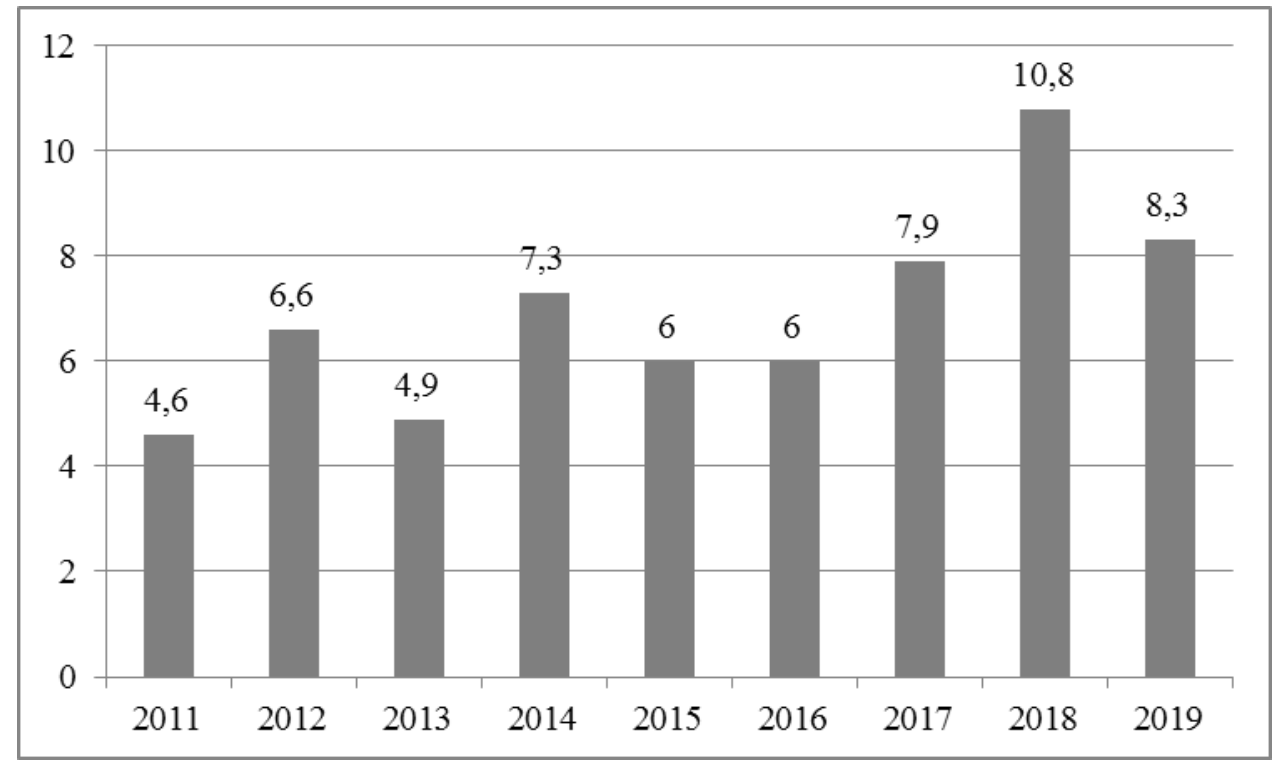

Figure 2. Revenues from the export of Russian grain in 2011-2019, billions dollars. Compiled by the authors based on the source agribusiness expert and analytical center.ru (Statistics of agricultural raw materials and food markets, $\mathrm{n} / \mathrm{d}$ )

Due to the export of wheat, the main foreign exchange inflow for agribusiness is formed, allowing to strengthen the level of international competitiveness of domestic agricultural production, forming close international cooperation with countries of different geographic zones. For example, according to the 2019/2020 agricultural year, the main buyers of barley and corn are the countries of the Middle East - Saudi Arabia, Iran, Turkey, Jordan. These countries export 1,779 thousand tons of barley, i.e. $77.6 \%$ of total exports; Turkey and Iran import 759 thousand tons of corn, or 59\% of its total exports. Wheat has a significantly larger geography, primarily due to the volume of Russian exports. In addition to the traditional partners for the purchase of Russian grain from Turkey and Egypt, wheat is bought by the countries of both the Atlantic coast of Africa and Southeast Asia. 
REVISTA DE LA UNIVERSIDAD DEL ZULIA. 3ª época. Año 12 N 32, 2021

Danil Alekseevich Zyukin et al. // Directions and prospects for expanding the export ... 87-101

DOI: http://dx.doi.org/10.46925//rdluz.32.07

The most important factor in promoting Russian wheat on the world market is the wide geography of imports of this agricultural crop, due to the peculiarities of the conditions of its production, which are absent in many countries of the world, while the demand for it is ubiquitous. In the context of analyzing the structure of world wheat imports, we will rely on the data of 2017, as the most successful for Russia in view of the record harvest of 2020.

The main buyers of wheat are the countries of Asia and Africa. Due to the socio-ethnic change in the composition of the population of Europe, the value of imports of its countries is also growing. Countries in the Americas such as Oceania are not major importers, mostly meeting their own needs. In addition, Russian interest here is minimal, due to the geographical remoteness and the presence of large players in grain export - Canada, USA, Australia (Zyukin et al., 2020a). Proceeding from this, the Asian market, as the largest in terms of wheat imports and the fastest growing due to the countries of Southeast Asia, is the most attractive for Russia, for which a traditional pool of importers in the Middle East has already formed. Also promising for Russian wheat should be considered the African market, which is logistically not so convenient for other major world grain exporters, despite the reduction in purchases by North African countries.

According to the results of the last agricultural season, Russia took a confident first place in wheat export; every fifth exported ton of wheat in the world falls on the share of domestic farmers, which brought in revenues of 8.4 billion dollars. The main competitors are North American grain producers in the United States and Canada, but they are focused more on other markets. The EU countries (mainly France) and Ukraine impose more competition due to geography. The rest of the exporters account for less than $30 \%$ of the wheat market (Figure 3).

In this regard, it is fundamentally important for Russia to maintain its competitiveness in the markets of its stable partners, which remain the countries of the Middle East and Egypt. The geography of Russian wheat supplies is growing: if 761 million dollars was accounted for by insignificant importers in 2017, it is $83 \%$ in 2019. Relative to the record level of 2018, most importers have reduced their niche, with the exception of 2 partners from the TOP-3: Turkey and Bangladesh, as well as the UAE. At the same time, the import of Russian wheat presented in Table 1 in 2019 decreased slightly - by 48 million dollars. Among the major partners in the top 10 in imports, significantly reduced supplies to 
REVISTA DE LA UNIVERSIDAD DEL ZULIA. 3ª época. Año 12 N 32, 2021

most countries: Saudi Arabia stopped importing wheat from Russia; Egypt, Vietnam and Lebanon reduced imports by more than 160 million dollars; Sudan, Yemen and Nigeria reduced by 60 million dollars to 80 million dollars (Table 1 ).

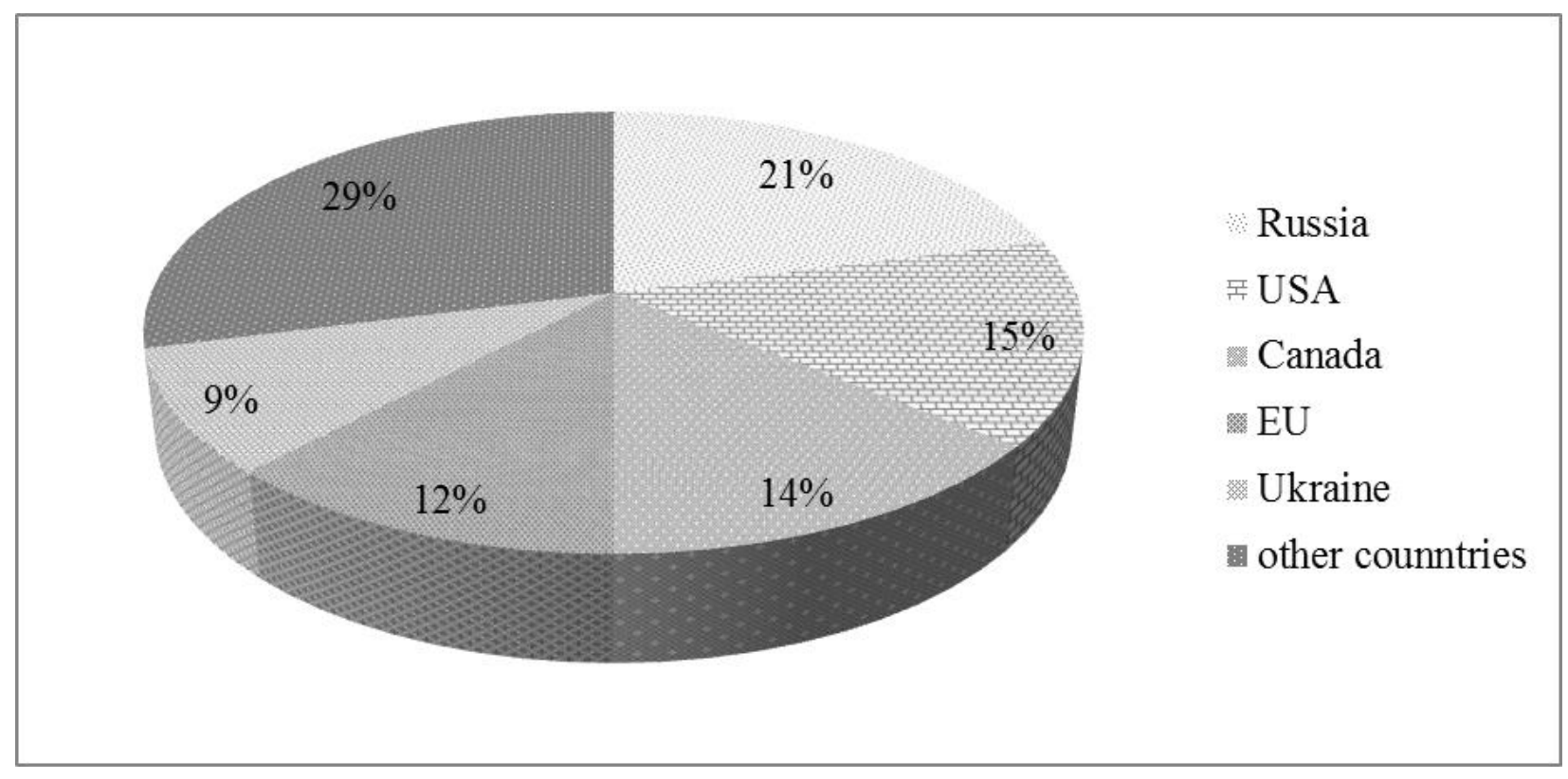

Figure 3. The share of exporting countries in the world wheat market in the season 2018-2019

Compiled by the authors based on the source agribusiness expert and analytical center.ru (Statistics of agricultural raw materials and food markets, $\mathrm{n} / \mathrm{d}$ )

It turns out that only Turkey and Bangladesh among the main importers of wheat have increased the volume of cooperation. This proves the instability of the situation in the global wheat market and highlights the great competition in this market. Russia needs to look for new partners on the world map, which incurs corresponding additional marketing and logistics costs. It is important to improve conditions to maintain not only export opportunities through high yields of wheat, but also to ensure the implementation of projects that reduce transport and logistics costs. Given the role in the mechanism of functioning of the Russian agro-industrial complex and significant export prospects at the level of over 10 billion dollars, the state can and should play a more active role in creating favorable conditions for exporters while maintaining the interests of the domestic market (Zyukin, 2020). 
REVISTA DE LA UNIVERSIDAD DEL ZULIA. 3ª época. Año 12 N³2, 2021

Danil Alekseevich Zyukin et al. // Directions and prospects for expanding the export ... 87-101

DOI: http://dx.doi.org/10.46925//rdluz.32.07

Table 1. Dynamics of export volumes of wheat from Russia by country and their position in Russian export

\begin{tabular}{|c|c|c|c|c|c|c|}
\hline \multirow{2}{*}{ Countries } & \multicolumn{2}{|c|}{2017} & \multicolumn{2}{c|}{2018} & \multicolumn{2}{c|}{2019} \\
\cline { 2 - 7 } & $\begin{array}{c}\text { amount, } \\
\text { million } \\
\text { dollars }\end{array}$ & place & $\begin{array}{c}\text { amount, } \\
\text { million } \\
\text { dollars }\end{array}$ & place & $\begin{array}{c}\text { amount, } \\
\text { million } \\
\text { dollars }\end{array}$ & place \\
\hline Turkey & 550 & 2 & 926 & 2 & 1374 & 1 \\
\hline Egypt & 1434 & 1 & 1893 & 1 & 1273 & 2 \\
\hline Bangladesh & 321 & 3 & 368 & 7 & 525 & 3 \\
\hline Azerbaijan & 230 & 10 & 120 & 16 & 257 & 4 \\
\hline Sudan & 264 & 6 & 417 & 4 & 204 & 5 \\
\hline Yemen & 267 & 5 & 265 & 8 & 189 & 6 \\
\hline Nigeria & 256 & 8 & 404 & 6 & 181 & 7 \\
\hline UAE & 174 & 12 & 139 & 14 & 150 & 8 \\
\hline Latvia & 83 & 17 & 221 & 11 & 108 & 9 \\
\hline Vietnam & 273 & 4 & 477 & 3 & 107 & 10 \\
\hline Tanzania & 123 & 13 & 152 & 13 & 104 & 11 \\
\hline Kenya & 116 & 14 & 160 & 12 & 101 & 12 \\
\hline Morocco & 47 & 18 & 104 & 17 & 99 & 13 \\
\hline Georgia & 88 & 16 & 86 & 18 & 86 & 14 \\
\hline Lebanon & 242 & 9 & 258 & 10 & 83 & 15 \\
\hline Israel & 105 & 15 & 139 & 15 & 74 & 16 \\
\hline Indonesia & 201 & 11 & 259 & 9 & 72 & 17 \\
\hline Saudi Arabia & 261 & 7 & 404 & 5 & 0 & 18 \\
\hline The rest of the world & 761 & $\mathrm{x}$ & 1644 & $\mathrm{x}$ & 1393 & $\mathrm{x}$ \\
\hline Total & 5796 & $\mathrm{x}$ & 8436 & $\mathrm{x}$ & 6380 & $\mathrm{x}$ \\
\hline
\end{tabular}

* Compiled by the authors based on the source Ru-stat.com (Export and import of Russia by goods and countries, $\mathrm{n} / \mathrm{d}$ )

Refusal of an active regulatory role can lead, with different options for grain yields, to unfavorable current and strategic prospects for the development of grain farming. Exports should remain an effective instrument of reorganization, creating conditions for increasing production within the country while fully meeting the needs for high-quality wheat and other types of cereals. The key point is the inaccessibility of "long-term investment money", which predetermines the small number of infrastructure and logistics projects implemented by businesses. Easing monetary policy or creating favorable conditions for business to attract credit resources is extremely necessary in the current situation in the country's economy. The second mechanism for supporting such projects is the formation of a mechanism of 
REVISTA DE LA UNIVERSIDAD DEL ZULIA. 3ª época. Año 12 N 32, 2021

Danil Alekseevich Zyukin et al. // Directions and prospects for expanding the export ... 87-101

DOI: http://dx.doi.org/10.46925//rdluz.32.07

preferences for investments in projects for the development of production and logistics infrastructure. Direct participation of the state is advisable in the form of development of the existing road transport network. The existing mechanism of subsidizing the interest rate on loans, in our opinion, is not effective and bears a compensatory nature, eventually flowing in favor of the financial sector.

\section{Discussions}

Despite the significant success in increasing the volume of grain supplies to the world market, the industry still has a number of difficulties and problems that stand out especially in times of crisis. In the context of increasing export potential, the state of the logistics infrastructure remains a key problem that still requires an acute solution (Zyukin, 2018). For Russia and Ukraine, there is a common problem of not the most successful geographical location of the main zone for shipping grain for export during sea transportation through the ports of the Azov-Black Sea basin. This narrows the list of major grain importers to certain regions, for example, the countries of Mediterranean Africa and the Middle East, and it is necessary to form new logistics routes for other geographic zones (Nekrasenko et al., 2019; Zyukin and Soloshenko, 2019).

The experience of the main exporters in the world grain market shows the importance of having an effective logistics network in the country as an integral element of ensuring the competitiveness of products (Fuller et al., 2003). Svanidze M. and Götz L. note in the context of a decrease in world prices for grain, the importance of trade costs becomes decisive (Svanidze and Götz, 2019). Another drawback is the low level of involvement of domestic agribusiness in the digital economy. Research by Andreeva E.L., Glukhikh P.L., Krasnykh S.S. shows the relationship between the volume of exports of technological products and the expected parameters of influence, including the integrated index of digitalization (Andreeva et al., 2020).

The demand for grain will persist even amid a slowdown in many economic processes due to the global pandemic, as it is one of the most important products. The main market for Russian wheat is precisely the countries of Africa and Southeast Asia, where a trend of population growth is observed with an increasing demand for cheap food (Zyukin et al., 
REVISTA DE LA UNIVERSIDAD DEL ZULIA. 3ª época. Año 12 N 32, 2021

Danil Alekseevich Zyukin et al. // Directions and prospects for expanding the export ... 87-101

DOI: http://dx.doi.org/10.46925//rdluz.32.07

2020b). At the same time, Russian wheat has a relatively high protein content, forming a predominant market niche for a number of importers (Panteleeva and Panteleeva, 2018).

However, there are also threats in the current trend. Given the structure of wheat produced in Russia with an extremely small share of high-quality varieties, such a situation can trap domestic production, which will be concentrated in other markets, creating a shortage of high-quality wheat in the domestic market (Altukhov, 2020). It is important to develop exports, but not to the detriment of food supply for the country's citizens, therefore, it is necessary to maintain a balance between the interests of the domestic market and obtaining foreign exchange earnings, predetermining the increase in the state's importance in managing the country's grain balance (Tyupakov et al., 2019).

The role of the state in the development of exports varies considerably. G.V. Kuznetsova, L.I. Tsedilin see opportunities for export development through increasing the role of export promotion agencies, which provide support to exporters through information support and training, provide marketing services, including organizing exhibitions and business missions, conducting market research for exporters (Kuznetsova and Tsedilin, 2018). In modern realities, Russia may well use political instruments promoting domestic products and vice versa - through the export of strategically important products to improve partnerships in the field of politics. At this stage, the weak ruble is a contributing factor, which is beneficial for exporters.

\section{Conclusions}

Wheat is the main product in the export of grain, which accounts for up to $80 \%$ of all foreign exchange earnings. This predetermines the interest on the part of business in increasing its yields, the bulk of which is exported. On the one hand, this is an opportunity to ensure an increase in the volume of grain production in physical weight and to receive additional income, but at the same time there is another side - the export-oriented structure of crops. The grain-product subcomplex is a backbone element of the agro-industrial complex, and therefore it is very important to manage the structure of grain production, which should take into account the needs of the domestic market. Export, first of all, is a reorganization tool that allows you to effectively regulate the situation in the domestic 
REVISTA DE LA UNIVERSIDAD DEL ZULIA. 3ª época. Año 12 N 32, 2021

Danil Alekseevich Zyukin et al. // Directions and prospects for expanding the export ... 87-101

DOI: http://dx.doi.org/10.46925//rdluz.32.07

market, so its increase should not become a strategic goal for the development of the subcomplex.

Russia has become a leader in wheat production and has enough resources to remain the main player, however, the peculiarity of the world grain market is its instability, therefore, the grain industry in Russia must have a number of characteristics. An urgent problem is the unstable nature of the harvest, which makes it difficult to maintain its position in some markets, and even expand the geography of supplies. It is not economically feasible to actively promote products to a new market if there is a serious risk next year that there will not be enough products to supply.

Also, a global economic task for Russia is to improve the production and logistics infrastructure of the grain-product sub-complex of the agro-industrial complex, which also contributes to increasing the competitiveness of Russian grain in the world market and expanding the possibility of its movement along the country's transport routes. Now the main point of shipment of Russian wheat is the ports of the Azov-Black Sea basin. New opportunities are opening up for supplies to the markets of Southeast Asia, as well as tense relations with Turkey, first in the context of the Syrian issue, now the conflict between Armenia and Azerbaijan. Therefore, in order to enter the markets of the countries of Atlantic Africa and Pacific Asia, it is important to diversify the development of port infrastructure in the Baltic Sea and the Far East.

Both strategic tasks for a sustainable increase in grain production and the development of production and logistics infrastructure cannot be comprehensively and quickly solved by private capital in the current difficult economic, social and political conditions without the influence of the state. Cloud technologies are underdeveloped in Russia, and there is still a low level of digitalization and the use of information systems in production management and export logistics. The key problem is the inaccessibility and high cost of long-term money with the already existing high debt load of agribusiness, as well as the absence of an adequate mechanism of tax preferences. In the context of the structural crisis and the fight against the coronavirus pandemic, an increase in direct subsidies for projects in the agricultural sector is not expected. However, the state has instruments of fiscal and monetary policy, the effective application of which can be traced to the example of Russia's main competitors in the world grain market. 
REVISTA DE LA UNIVERSIDAD DEL ZULIA. 3ª época. Año 12 N 32, 2021

Danil Alekseevich Zyukin et al. // Directions and prospects for expanding the export ... 87-101

DOI: http://dx.doi.org/10.46925//rdluz.32.07

\section{References}

Altukhov, A. I. (2017). Development of grain production in the country: myths and reality. Economy of agriculture of Russia, 3, 31-39.

Altukhov, A. I. (2020). Russian grain export: pros and cons of development. Bulletin of the Kursk State Agricultural Academy, 5, 166-174.

Andreeva, E. L., Glukhikh, P. L. and Krasnykh, S. S. (2020). Assessment of the impact of digitalization processes on the development of technological export of Russian regions. Economy of the region, 16 (2), 612-624.

Belova, T. N. (2019). Processes of import substitution in the agri-food sector. Economy of the region, 15 (1), 285-297.

Export and import of Russia by goods and countries (n/d). Available at: https://rustat.com/date-M201812-201906/ru/export/world/0210.

Fuller, S., Yu, T.-H., Fellin, L., Lalor, A. and Krajewski, R. (2003). Effects of improving transportation infrastructure on competitiveness in world grain markets. Journal of international food and agribusiness marketing, 13 (4), 61-85.

Generalov, I. G. (2018). Factors of economic efficiency of grain production in the region under different agro-climatic conditions. Azimuth of scientific research: economics and management, 7, 2 (23), 114-116.

Krylatykh, E. N. and Belova, T. N. (2018). Export of Russian grain in the context of the formation of regional economic policy. Economy of the region, 14 (3), 778-790.

Kuznetsova, G. V. and Tsedilin, L. I. (2018). Stimulation of non-resource exports: international experience and Russian practice. World Economy and International Relations, $62(5), 72-79$.

Nekrasenko, L., Pittman, R., Doroshenko, O., Chumak, V. and Doroshenko, A. (2019). Grain logistics in Ukraine: the main challenges and effective ways to reach sustainability. Economic Journal-XXI, 178 (7-8), 70-83.

Panteleeva, M. A. and Panteleeva, O. B. (2018). Analysis of development trends of the grain market in the context of modernization of the national economy of Russia. Economy of sustainable development, 2 (34), 233-238.

Statistics of agricultural raw materials and food markets. Official website of the agribusiness expert and analytical center (n/d). Available at: https://ab-centre.ru/statonline/l.

Svanidze, M. and Götz, L. (2019). Spatial market efficiency of grain markets in Russia: implications of high trade costs for export potential. Global Food Security, 21, 60-68. 
REVISTA DE LA UNIVERSIDAD DEL ZULIA. 3ª época. Año 12 N 32, 2021

Danil Alekseevich Zyukin et al. // Directions and prospects for expanding the export ... 87-101

DOI: http://dx.doi.org/10.46925//rdluz.32.07

Svetlov, N. M. (2016). How to withstand uncertainty in Russian wheat market. News of the Timiryazev Agricultural Academy, 6, 108-129.

Tyupakov, K. E., Reznichenko, D. S., Klochko, E. N., Verty, M. V. and Cherner, N. V. (2019). Development of the grain market export potential. International Journal of Recent Technology and Engineering, 8 (3), 7146-7152.

Zavriev, S. K. and Ignatov, A. N. (2020). Potential Threats to Agricultural and Food Security. World Economy and International Relations, 64 (7), 100-107.

Zyukin, D. A. (2018). The state of the grain products subcomplex of the agro-industrial complex of Russia in the context of the expansion of economic space and food embargo. Azimuth of scientific research: economics and management, 7, 3 (24), 100-103.

Zyukin, D. A. and Soloshenko, R. V. (2019). Improving transport and logistics infrastructure as a basis for increasing the efficiency and diversification of Russian grain exports. Bulletin of the Kursk State Agricultural Academy, 7, 141-147.

Zyukin, D. A. (2020). Model of economic and state regulation of the development of the grain market infrastructure. International agricultural journal, 1, 47-50.

Zyukin, D., Pronskaya, O., Golovin, A. and Belova, T. (2020a). Prospects for increasing exports of Russian wheat to the world market. Amazonia Investiga, 9 (28), 346-355. DOI: https://doi.org/10.34069/AI/2020.28.04.39

Zyukin, D., Svyatova, O. and Soloshenko, R. (2016). Conditions and perspectives of Russian sugar market development. Economic annals, 161 (9-10), 47-50.

Zyukin, D., Svyatova, O., Zolotareva, E., Bystritskaya, A. and Alyokhina, A. (2020b). The improvement of the model to develop the infrastructure of the grain product subcomplex as the essential attribute to increase the efficiency and ramp up of Russian grain export. Amazonia Investiga, 9 (25), 461-470. 